\title{
RESEARCH AND CONSERVATION IN MARINA EL-ALAMEIN IN 2014 AND 2015 (POLISH-EGYPTIAN CONSERVATION MISSION) Part two: The Hellenistic Baths
}

\author{
Rafał Czerner, 'Grażyna Bąkowska-Czerner, Wiesław Grzegorek ${ }^{3}$ \\ and Grzegorz Majcherek ${ }^{4}$ \\ ${ }^{1}$ Wrocław University of Science and Technology, ${ }^{2}$ Jagiellonian University, ${ }^{3}$ independent, PCMA \\ associate, ${ }^{4}$ Polish Centre of Mediterranean Archaeology, University of Warsaw
}

\begin{abstract}
In 2014 and 2015, the Polish-Egyptian Conservation Mission to Marina el-Alamein undertook research, conservation and presentation of the area north of the central square of the ancient town. A major landmark in this part of the city are the public baths from the Hellenistic period, discovered in 1987. The work was focused on the main chambers of the bath: the central tholos with relics of hip-bathtubs, the neighboring room with an immersion bathtub, and a set of rooms in the southern area of the complex.
\end{abstract}

Keywords: Marina el-Alamein, Hellenistic baths, architecture, research, preservation, conservation

The remains of public baths to the north of the main town square were one of the work priorities of the Polish-Egyptian Conservation Mission working in the 2014 and 2015 season on research, conservation and exhibition of historic monuments at the site of ancient Marina el-Alamein [Fig. 1]. Activities in the bath were undertaken for the first time since the discovery of the complex in 1987 (Daszewski 1991: 16; 1995: 18, Fig. 4; 2011: 429; Fournet et al. 2013: 326).
The team embarked on the project in 2014, commencing research on the architecture of the baths which were dated to the Hellenistic period and were evidently earlier than the porticoes surrounding the square. The main bath chambers: the tholos (1) in the center and the neighboring rooms ( 2 and $2 \mathrm{a}$ ) were cleared and preserved. Their walls were restored, partly with original blocks, but new courses were also added on top. The most eroded elements were replaced, and 
the joints were filled. Some elements made of bricks, that is the dome base in room 1 and relics of the bathtub edge, were filled or partly reconstructed. The work contributed to better legibility of the layout of this part of the complex. Some walls of other rooms also underwent conservation. In 2015, the research was broadened to include the area of the baths situated to the west and south of the tholos, in rooms $2 b, 6,7,8$ and 8a. They were cleared and preserved; their walls were restored. The edges of the water reservoir (3), made of bricks and plastered, were preserved. An analysis of the functional layout of the baths was undertaken. It confirmed the main findings made at the time of discovery and contributed new details. The scope of the major transformations was identified.

$[\mathrm{RC}]$

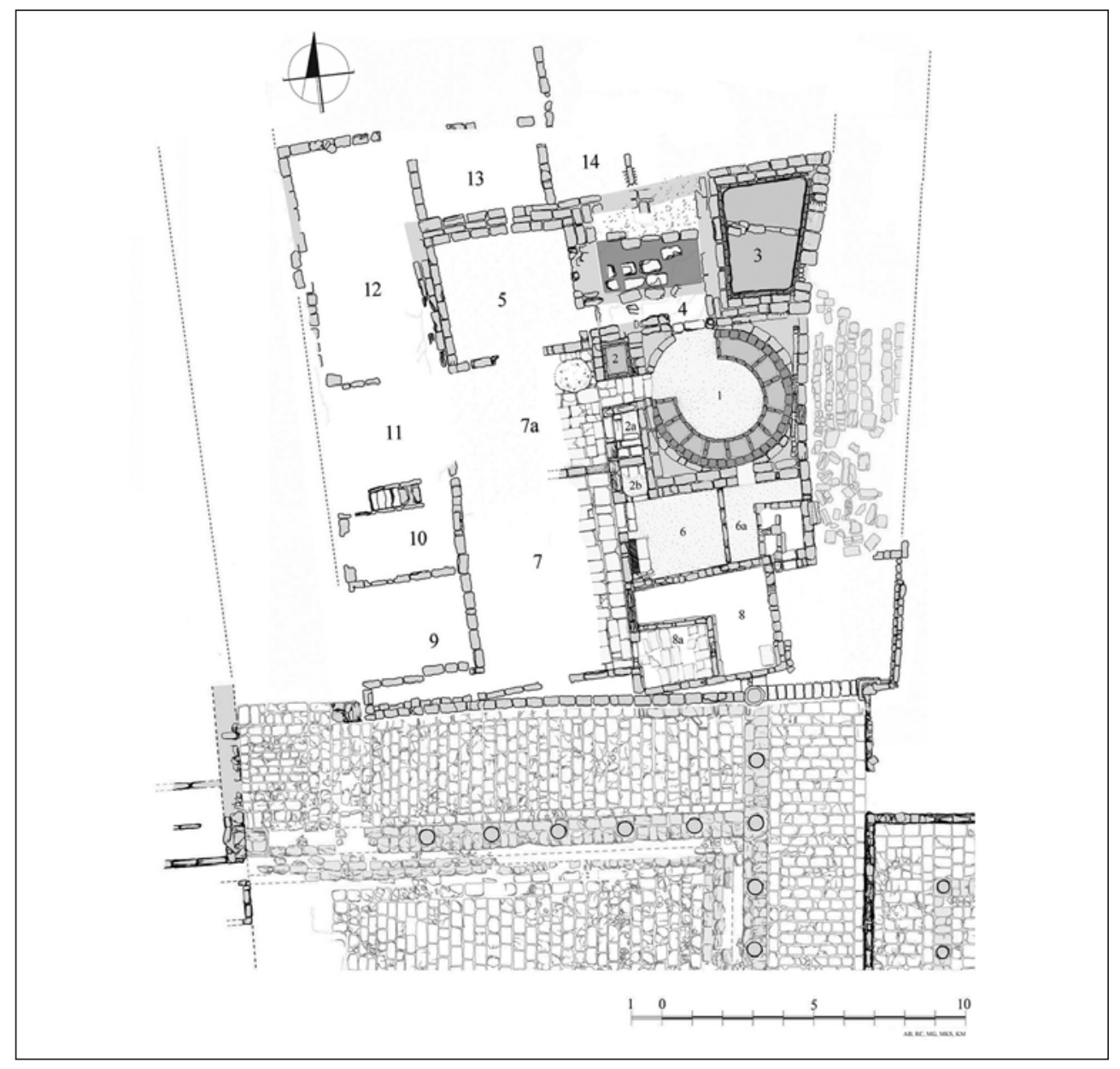

Fig. 1. Hellenistic baths north of the main town square, general plan

(Drawing A. Btaszczyk, R. Czerner, M. Grzegorek, M. Krawczyk-Szczerbinska, K. Majdzik) 


\section{ARCHITECTURAL DESCRIPTION}

The tholos (1) is the main chamber of the baths. It is $4.78-4.83 \mathrm{~m}$ in diameter and $1.86-1.95 \mathrm{~m}$ high, measuring from the floor to the base of a dome once crowning it [Figs 1, 2]. Walls of upright limestone slabs, $0.20-0.21 \mathrm{~m}$ wide, were built into a trapezoid room widening to the northeastern corner, with two right-angled west corners. The internal measurements of the room walls were: $5.18 \mathrm{~m}$ (north), $4.70 \mathrm{~m}$ (east) and $4.65 \mathrm{~m}$ (west and south). Its walls were $0.53-0.55 \mathrm{~m}$ thick and strong enough to support a dome. The dome was made of red bricks sized $20 \times 20 \times 3 \mathrm{~cm}$. Its base was supported on peripheral walls constructed of thin slabs, and by setoffs

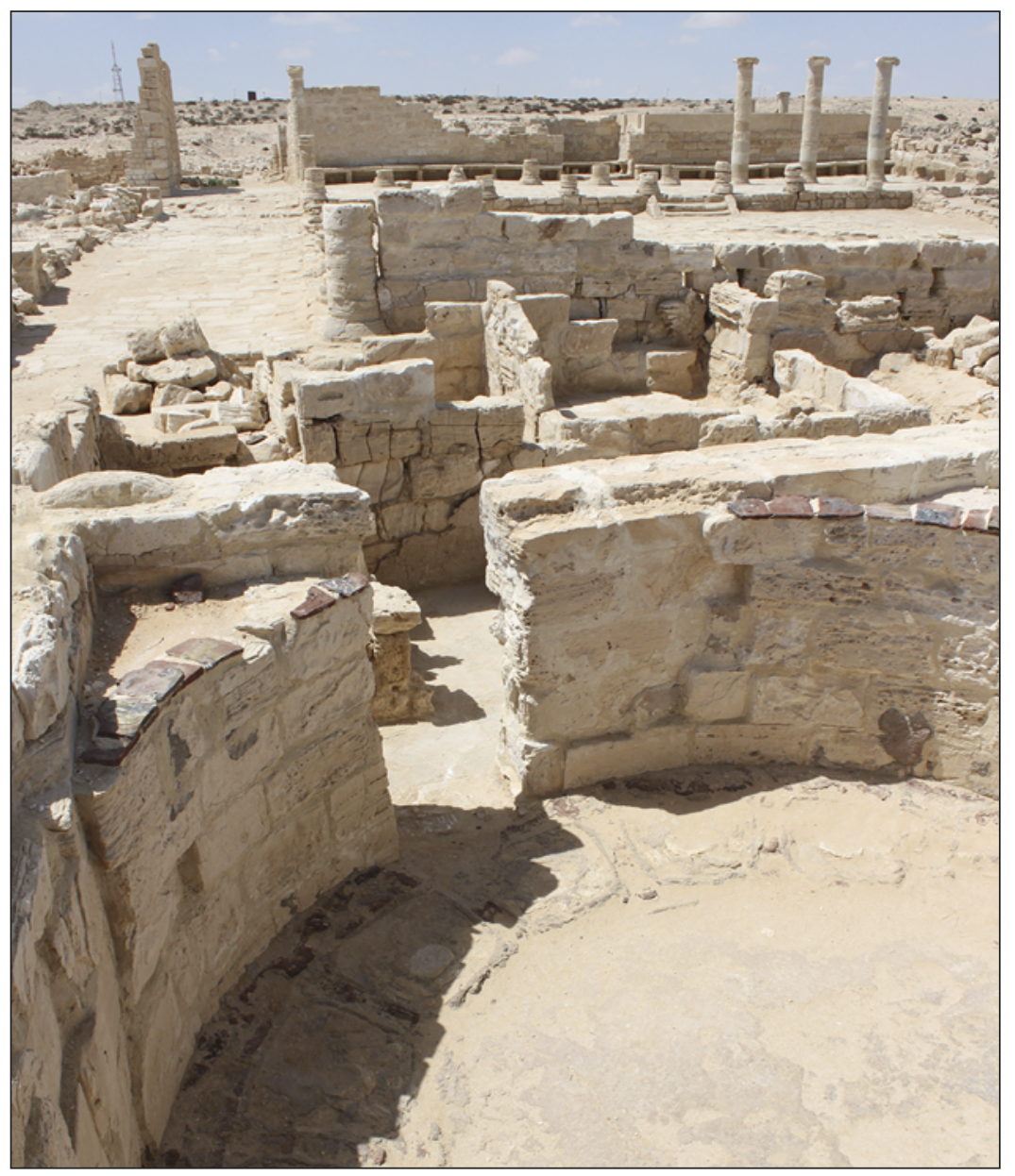

Fig. 2. Tholos and the southern part of the baths in 2015; view looking south with the main town square and restored columns of the South Portico in the background (Photo R. Czerner) 
carved in the middle of each thick wall of the trapezoid quadrangle. Nine hipbathtubs with rounded corners were located around the chamber. The average internal measurements were $0.48-0.63 \mathrm{~m}$ by $0.54 \mathrm{~m}$. A bathtub almost three times as big as the others was installed at the end of the row on the northwest. It was probably intended for immersion. All the tubs were built of bricks and brick halves, and lined with mortar. A smoothed, slightly concave round block of limestone was placed in the center of the bottom of each tub. The flooring of the chamber was made of limestone slabs covered with poured mortar, applied in several layers one by one. There were two entrances originally: one from the west, with jambs on the outside and thus closed by a door, the other from the north, without jambs. Another entrance, from the south, was made later.
The western entrance connected the tholos with a small rectangular room (2) which was $0.92 \mathrm{~m}$ by $2.03 \mathrm{~m}$ and which could also be reached from the opposite direction, that is, from the west, probably directly from the entrance to the bath. The northern part of the room was occupied by an immersion bathtub with internal measurements of $0.62 \mathrm{~m}$ by $0.92 \mathrm{~m}, 1.20 \mathrm{~m}$ deep, built of brick halves and lined with waterproof mortar. South of room 2 there was an annex adjacent to the western outer wall of the tholos, with the same width of $0.92 \mathrm{~m}$ and length of $3.00 \mathrm{~m}$. It housed stairs leading to the upper storey [Fig. 3]. The stairs began with three steps from the west and then, past the landing, they turned south. Rooms 2 and 2a were added to the tholos. Even so, they represented most probably the same phase of functioning of the bath as the tholos.

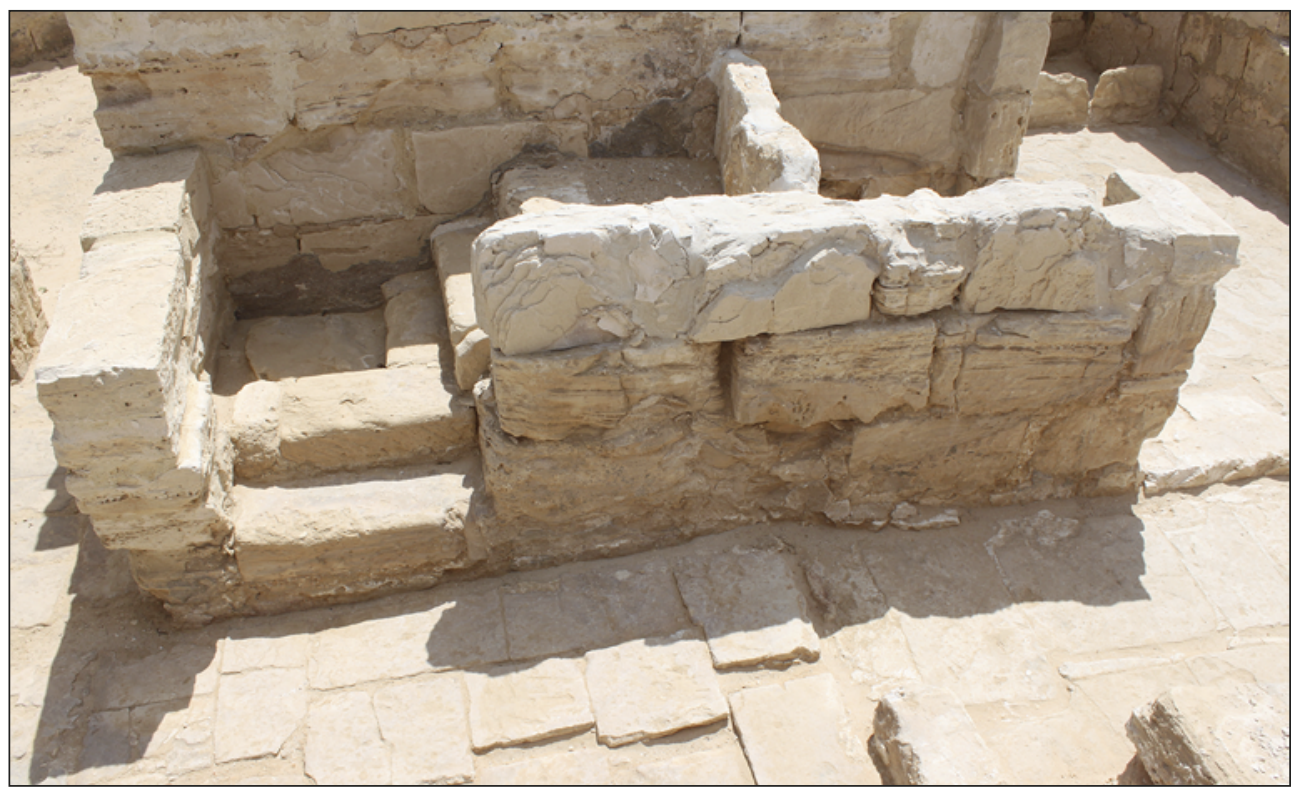

Fig. 3. Staircase (2a), after conservation in 2014 and 2015 (Photo R. Czerner) 
The northern entrance connected the tholos with room 4, a greater part of which is still filled with rubble. The heating device was located there. The middle part of the room was sectioned off from both the north and the south by inner walls of limestone blocks. Relics of a structure made of red bricks in clay mortar were found there. The device was operated through an opening on the northern side. From the southern part of room 4 an entrance led to the west, to room 5. It was walled in during a later phase. East of room 4 was a water reservoir of trapezoid shape, $3.64 \mathrm{~m}$ long $\mathrm{N}-\mathrm{S}$, $2.10 \mathrm{~m}$ wide to the south and $2.94 \mathrm{~m}$ to the north, set on a high substructure. Its walls were also built of red brick halves and lined (together with the bottom) with hydraulic mortar.

Room 6 south of the tholos was divided later into units 6 and $6 a$. Further to the south was room 8 , from which room 8 a was later separated. Adjoining this group of rooms on the west was room 7 , which has yet to be fully excavated [Fig. 4].

Room 6-6a, sized $5.88-6.00 \mathrm{~m}$ by $2.45-2.75 \mathrm{~m}$, was created by closing the space between the walls of the tholos and room 8. It was elongated from east to west and was divided in a later phase. The west wall of room $6,0.30 \mathrm{~m}$ thick, was built of limestone blocks. All the walls of room 8, including the northern one, were built of similar blocks. An entrance to room 7 appeared in the west wall of room 6 , by the northern corner; it was $1.30 \mathrm{~m}$ wide, furnished with two stone steps: one in the entrance and the other in front of it. By the same corner, in the north wall, there was a door to room $2 b$. The east wall of room 6 a doubled as the outer wall of the bath complex and was an extension of the

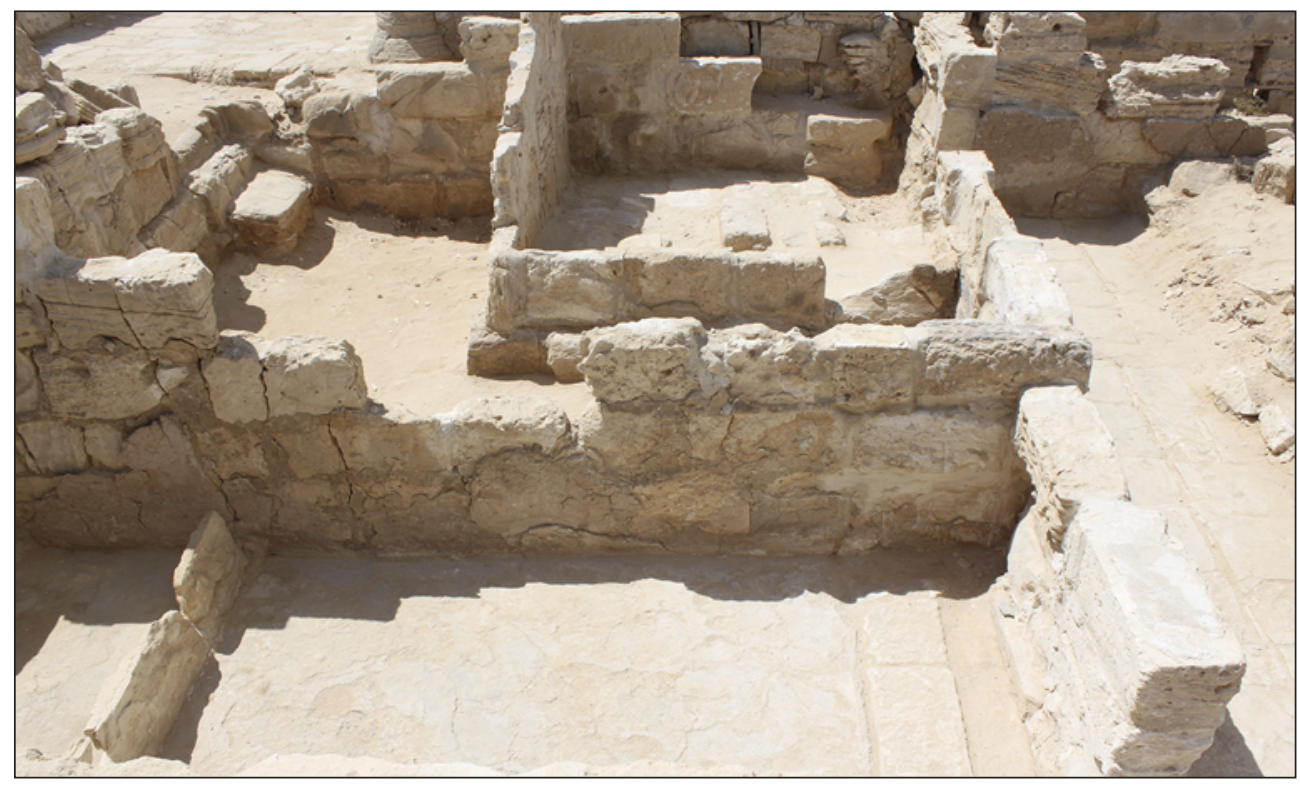

Fig. 4. Southern part of the baths after conservation in 2015

(Photo R. Czerner) 
east wall of the tholos to the south. It was $0.35 \mathrm{~m}$ thick. The eastern section of the south wall (in the part east of room 8) was exceptionally thick, that is, $0.60 \mathrm{~m}$. The room was later divided with a wall of flat slabs set upright on the flooring, $3.20 \mathrm{~m}$ from the west. A platform of big stone blocks was built on the floor in the southeastern corner of the room [Fig. 5].

Room 8 , sized $4.45-4.50 \mathrm{~m}$ by $3.30 \mathrm{~m}$, had three homogeneous walls, each $0.25-$ $0.28 \mathrm{~m}$ thick. Its south wall, narrower than the other three, was built of limestone blocks approximately $0.20 \mathrm{~m}$ thick. Its western end adjoined the wall of the main square portico, which is older than the south wall of room 8 (and the baths), and has a slightly different alignment. Two doors, $0.84 \mathrm{~m}$ and $0.70 \mathrm{~m}$ wide, were opened in the east and west walls. No flooring has survived in the room.
Room 8a was created in the southwestern part of room 8 in a later phase. It was $2.30 \mathrm{~m}$ by $1.70-1.90 \mathrm{~m}$. The north and east walls, $0.15-0.20 \mathrm{~m}$ thick, were made of upright slabs on a foundation of blocks of the same size as those used for the outer walls of room 8. Blocks of the same type, laid irregularly, were used for the flooring in room 8 a.

Room 7 was a spacious length, extended further north by the extension $7 \mathrm{a}, 6.57 \mathrm{~m}$ plus $3.86 \mathrm{~m}$, the width being about $5.10 \mathrm{~m}$. The north wall of room $7 \mathrm{a}$ and the wall separating the two rooms were each $0.20 \mathrm{~m}$ thick and made of limestone blocks. The flooring in both rooms was laid of limestone slabs $(0.40-0.55 \mathrm{~m}$ by $0.50-0.60 \mathrm{~m})$. A section $1.00-1.50 \mathrm{~m}$ wide was cleared along the east wall of both chambers.

$[\mathrm{RC}]$

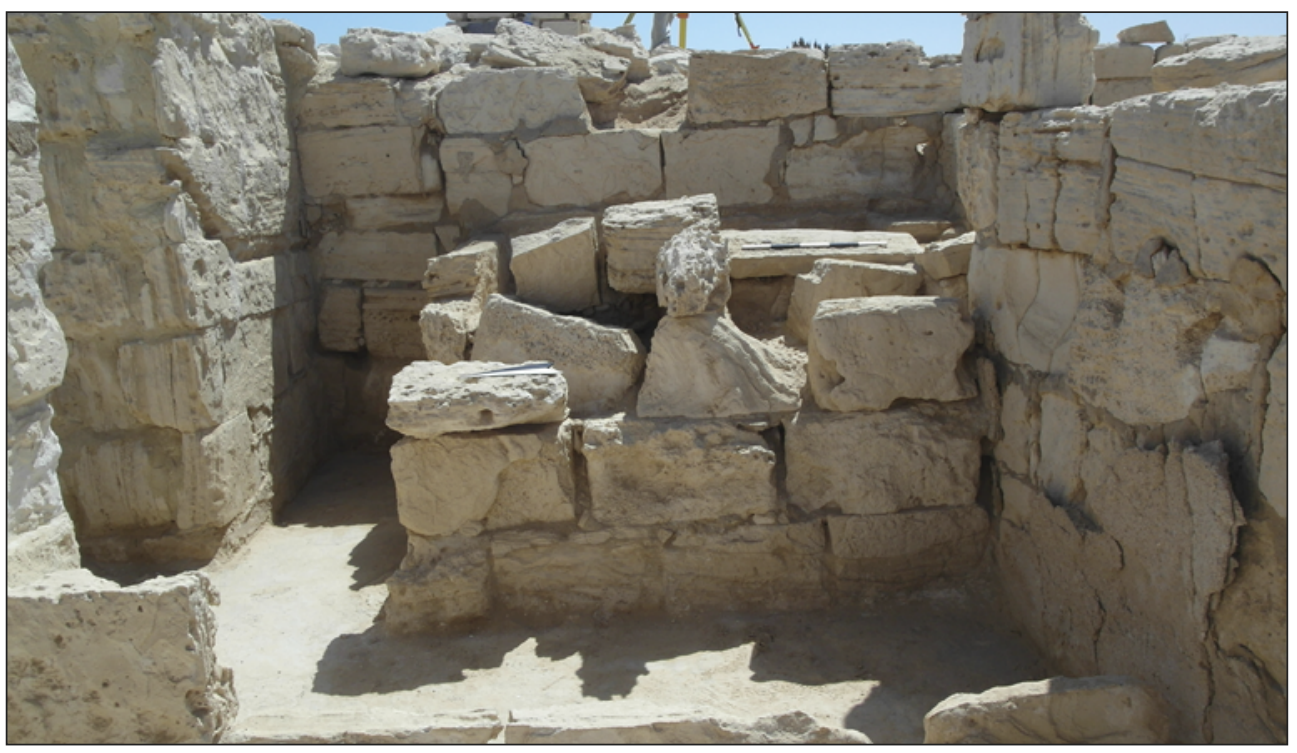

Fig. 5. Platform in the southeastern corner of room 6a in the Northern Bath (Photo G. Bąkowska-Czerner) 


\section{ARCHAEOLOGICAL RESEARCH}

The complex was cleared under archaeological supervision, the objective being to clarify the plan and to prepare the architecture for conservation. The fill inside the chambers was for the most part secondary, because the complex had been excavated already during salvage excavations in the late 1980s. Finds from undisturbed floor levels were dated to the 2nd and 3rd century horizon.

The tholos (1) was cleared [see Fig. 1]. The northern door, which was $1 \mathrm{~m}$ wide and led to room 4, turned out to be blocked with stone blocks resting on a layer of sand, $0.20 \mathrm{~m}$ thick, covering a threshold measuring $0.16 \mathrm{~m}$ in height. Room 4, sized $3.73 \mathrm{~m}$ by $3.55 \mathrm{~m}$, was not explored at this time. Only the upper layer of stone blocks, lying approximately $1.70-1.80 \mathrm{~m}$ above the floor, was cleared. A row of bricks set in clay mortar, found in the sand by the north wall, seems to have been a furnace. By the south wall there is a zone of clean sand abut $0.90 \mathrm{~m}$ wide; it is probably a corridor leading from the western entrance (later walled in) to the tholos.

In preparation for conservation, the stairs (2a) leading to the upper floor and the immersion bathtub (2) were cleared. Bricks were found to be smaller than those in the Southern Bath, that is, $20 \times 20 \mathrm{~cm}$, and $2 \mathrm{~cm}$ thick; one of these bricks featured an impression of an animal paw.

Chambers south of the tholos were partly cleared. These were chambers 6 and $6 a, 2 b, 8$, and 7 and $7 a$. In rooms 6 and $6 \mathrm{a}$, stone blocks collected during archaeological work in the 1980s were removed and the floor of mortar cleared. The room turned out to have been divided into two smaller units at a later stage. The partitioning wall (surviving $0.65 \mathrm{~m}$ high in the northern part and $0.15 \mathrm{~m}$ wide) of upright stone slabs stood directly on the floor [see Fig. 4]. The platform of stone blocks in the southeastern corner was $1.82 \mathrm{~m}$ by $1.65 \mathrm{~m}$ in plan and $1.50 \mathrm{~m}$ high. It was accessed through a door situated in the south wall [see Fig. 5]. A stairway (probably wooden) led upstairs from this platform. The structure must have been mounted making use of a slot cut in the north wall flush with the level of the platform. Cleaning of the platform produced several fragments of mortar with impressions of palm beams, as well as several pottery sherds and part of a terracotta figurine depicting the lower part of a nude boyish figure [Fig. 6], the

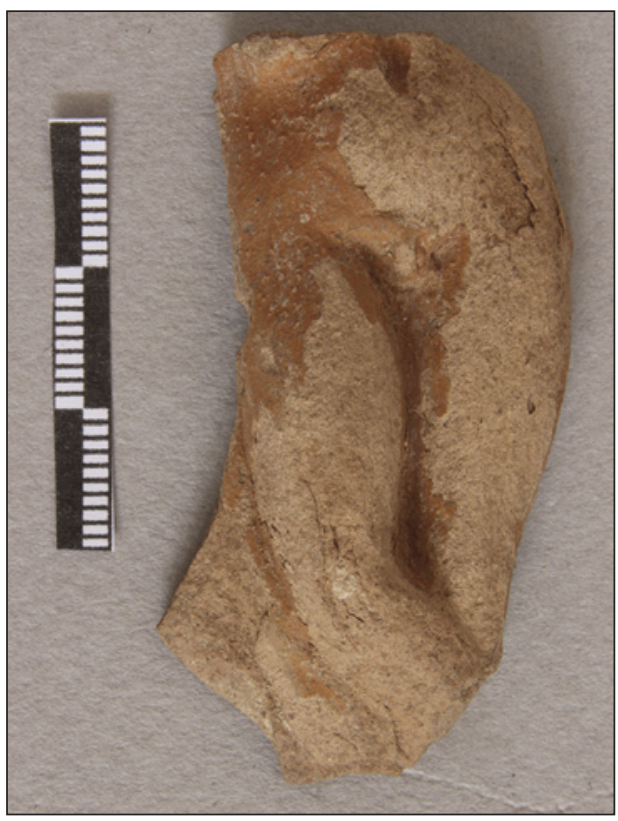

Fig. 6. Fragmentary terracotta depicting a nude boy (Photo R. Czerner) 
crossed legs bringing to mind Skopas's sculpture of Pothos. It resembles the depiction of a boy with a duck found in Lilaia in Phocis (Queyrel 2014: 134-135, Fig. 8). Unlike most copies of Skopas's statue, the terracotta from Marina has the weight of the body resting on the left leg, the right one being bent. Pothos from Florence is depicted in such a reversed position (Becatti 1941: 411, Pl. CXVI, Fig. 11).

A door in the western part of the room led up two steps to another chamber (7). A drain ran by the west wall; it was $1.20 \mathrm{~m}$ by $0.26 \mathrm{~m}$. The fill in the northwestern corner yielded several pieces of ceramics and glass. Remains of wall plaster with yellow showing up faintly in places were noted on the north wall. Fragments of waterproof plaster still survived on the opposite, south wall. Another door existed in room 6; a threshold $0.10 \mathrm{~m}$ high with door jambs survived in this doorway. The door led to a small room (2b) under the stairs.

Under the layer of rubble in room $2 \mathrm{~b}$ (approximately $0.70 \mathrm{~m}$ thick), $0.20 \mathrm{~m}$ above the floor, a big animal bone and broken pottery were found. The fill at floor level $(0.10 \mathrm{~m}$ thick) yielded ceramics and glassware, a small bone spoon and a base of a lamp with a Greek inscription. Waterproof plaster was recorded on the east and west walls of the room.

Several big stone blocks placed in room 8 during the explorations in the 1980 s were removed, uncovering a compact dark-colored deposit under a layer of pure sand. The finds included a small number of potsherds, glass, animal bones, and some evidence of small hearths. Black discolorations were noted on the north and east walls. In the western part of the room a small probe uncovered a layer of rubble $(0.10-0.15 \mathrm{~m})$ with clean loose sand below and stones under the foundation of the north and west walls. The room was entered originally from room 7 through a door $(0.84 \mathrm{~m}$ wide $)$ in the west wall. After room $8 \mathrm{a}$ had been built into the southwestern part of room 8 , the latter was entered most likely from the east through a door located in the southeastern corner.

The area uncovered in rooms 7 and $7 \mathrm{a}$ was $1.20 \mathrm{~m}$ wide and $10.75 \mathrm{~m}$ long, reaching as far as room 5. Scattered stone blocks tumbled from the walls were uncovered in a layer of sand. In the

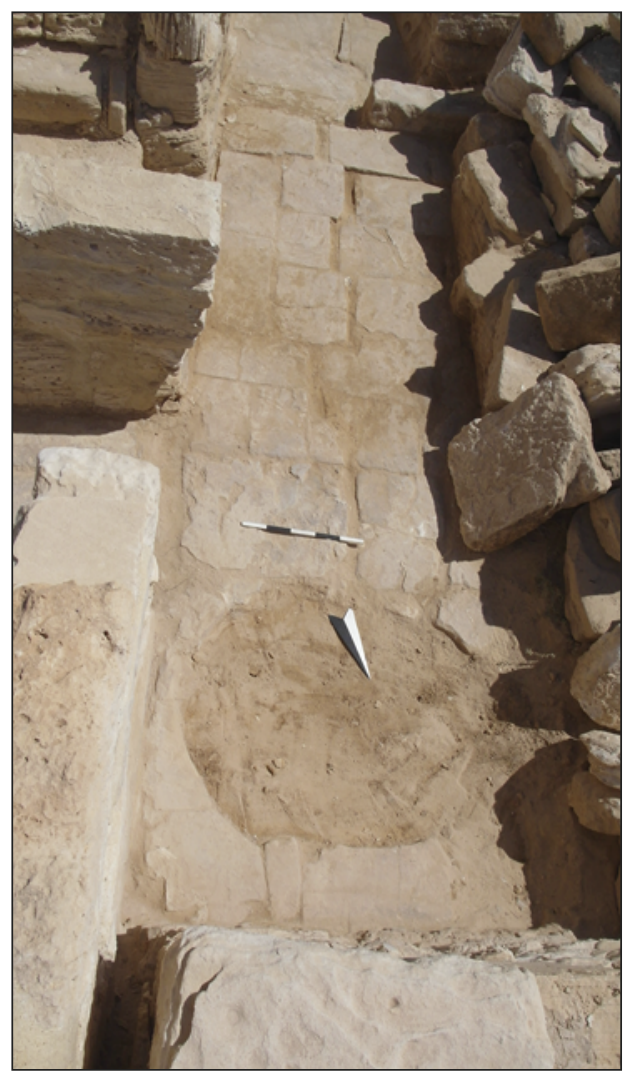

Fig. 7. Well in the northern part of rooms 7 and $7 a$ (Photo G. Bakowska-Czerner) 
northern part, stone blocks, originating from the exploration in the 1980s lay on the flooring. Several potsherds and a fragment of a marble vessel were found by the north wall. More potsherds were found in the fill accumulated directly on the floor. Waterproof plaster survived to a height of $1.30 \mathrm{~m}$ on the south wall.

A well was recorded by the immersion bathtub in the northern part of the complex. The oval opening was $1.00 \mathrm{~m}$ by $1.30 \mathrm{~m}$ in size [Fig. 7]. The well was not explored. Situated $3.90 \mathrm{~m}$ away from the wall of room 5, a low wall, $0.20 \mathrm{~m}$ wide, ran perpendicularly to the east wall of room 7 , sectioning off a room $6.57 \mathrm{~m}$ long on the south side. Room 7 gave access to chambers 6 and $8 \mathrm{a}$, whereas the tholos and staircase were entered from room $7 \mathrm{a}$.

$[\mathrm{GB}-\mathrm{C}]$

\section{POTTERY ASSEMBLAGE}

Pottery from the tholos bath came mostly from the fill, consequently, all the recorded fragments should be treated with due caution, as apparently re-deposited and therefore of little or no chronological value. Previous excavations in this part of the site, conducted in the 1980s, left behind large pottery dumps in the vicinity, which almost certainly contaminated even seemingly untouched strata. Nonetheless, the range of noted types and forms is largely similar to that previously excavated throughout the site. Most of the assorted ceramic finds represent a 2 nd-3rd century AD horizon; only a few could be assumed to be of pre-Roman date.

Transport amphorae and other common wares made for the bulk of the pottery finds. As noted in the case of the nearby Southern Bath (Czerner, Bąkowska-Czerner, and Majcherek 2015: 129-133; see also above, Czerner et al. 2016: 156159 , in this volume), the AE3 amphorae are by and large the most frequent group. Produced from distinctive calcareous marly clays, they were manufactured in numerous workshops located mostly on the southern shores of the Mareotis lake. The fabric is usually medium coarse, with abundant small to large lime grits, quite often erupting on the buff surface. The finds are very fragmentary; all the recorded fragments represent the usual morphological variation of rims, handles and overall body contour (Dixneuf 2011: 97-111, Figs 83-96). Only one well preserved tubular ribbed neck with two small loop handles attached under the rim was found in the bath, but on the surface [Fig. 8:1].

Several amphora fragments, of apparent Northwestern coast (Marmarica) origin (Rieger and Möller 2011), were recognized but their exact type-form could not be determined unambiguously. They were made from a medium coarse, calcareous paste, usually fired to light red color. The frequently encountered creamish-white skin, which is a conspicuous feature of this ware, apparently resulted from the use of saline water in the manufacturing process. While most of the sherds come from the Roman period, some may be presumed to be of earlier date. Similar amphorae, dated to the Late Ptolemaic (AE2) and Early Roman (AE3) period, were identified at the Tel Haraby kiln-site, some $80 \mathrm{~km}$ west of elAlamein (Majcherek and Shennawi 1992).

Quite a number of sherds of "pinched handles" amphorae (Mau 27/28) were also 
noted in the fill. Amphorae of this type are undoubtedly the most numerous class of foreign vessels identified at Marina. Several fabric variants have been recognized, representing three basic production centers. However, most of the recorded examples should be attributed to fabrics defined as Cypriot (Lund 2000). Other production centers from Cilicia (Anemurium, Birkeci or Syedra) are represented only sporadically (Majcherek 2007: 21-24).

Cretan amphorae fragments (form AC1 predominates) (Majcherek 2007: 11-13) were again fairly common. A few examples of Dressel 2-4 type vessels, most probably of Laodicean origin, rather rarely reported at the site, were also identified [Fig. 8:2]. It is worth noting that these vessels, with their characteristic double-barrelled handles, are almost totally absent in Egypt with the exception of some Eastern Desert and Red Sea sites (Tomber 1998). Several fragments of Cilician Pompei 5 containers, as well as massive handles of an early version of Gaza-Ashkelon vessels (LRA4a) complete the repertoire of amphorae types.

Common wares were represented mostly by cooking pots. These rather small globular two-handled vessels, with rounded bottoms and outturned rims, were all invariably made in conspicuous Nile silt fabric, and all represented a 2nd century AD horizon. An interesting find is a large basin of apparent foreign origin (Italian?), with a rim that was grooved on its top [Fig. 8:3].

Fine wares were, as usual, limited almost exclusively to Cypriot Sigillata forms.

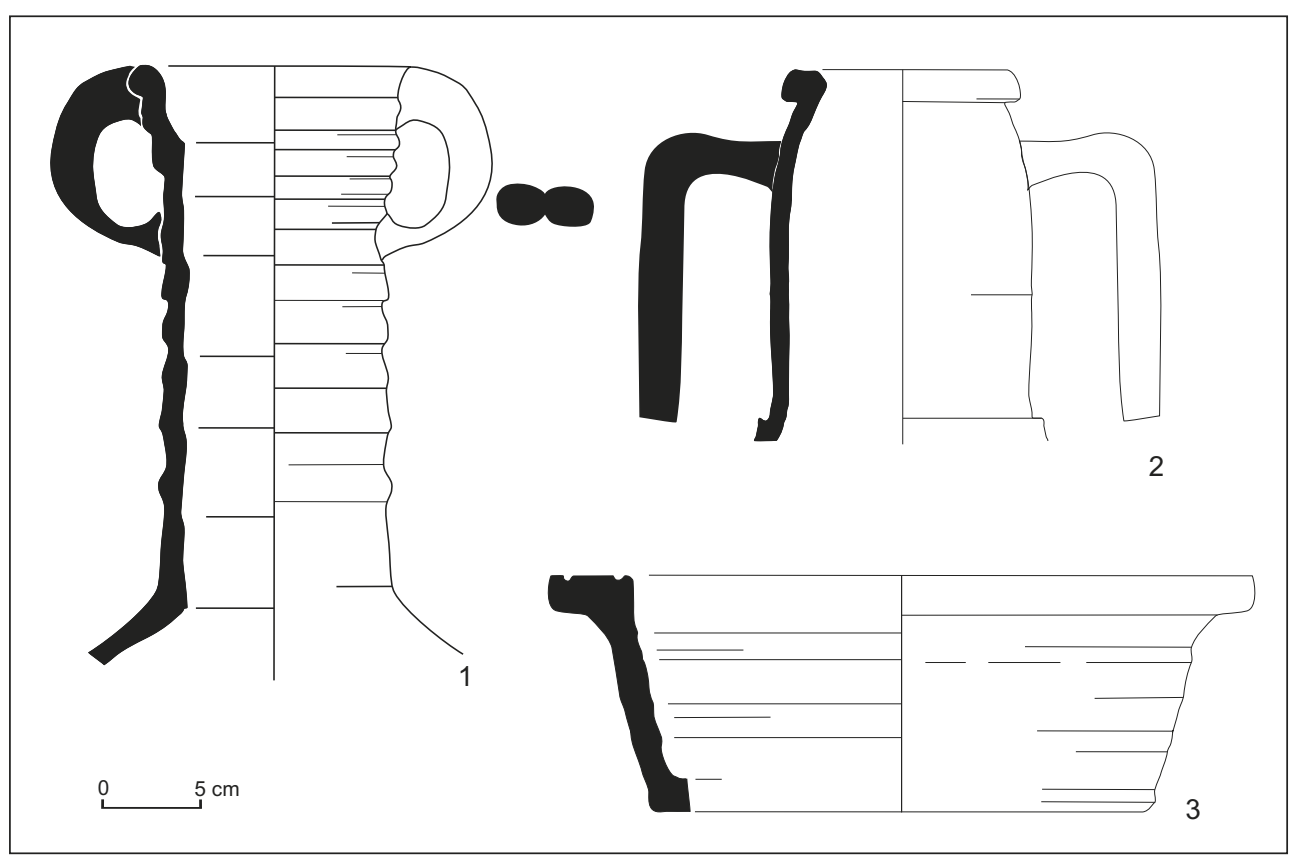

Fig. 8. Selection of pottery from the Northern Bath: 1-AE3 amphora neck; 2-Laodicean Dressel 2-4 amphora neck; 3 - basin of Italian(?) origin (Drawing G. Majcherek) 
Among them one should list several typical overhang rims of large bowls (form P40) dated to the first half of the 2 nd century $A D$ (Hayes 1985: 88). This is undoubtedly the most common tableware form at the site and a valuable chronological benchmark.
Several fragments of thin-walled cups in Nile silt fabrics were also registered. These, in turn, appear to be derivative of imported pareti sottili class vessels, also registered at the site.

$[\mathrm{GM}]$

\section{FUNCTIONAL LAYOUT OF THE BATHS}

Conclusions regarding the functioning of the bath, reached at the time of their discovery (Daszewski 1991: 16; 2011: 429; Fournet et al. 2013: 326) remain generally valid [see Fig. 1]. The central part of the bath was typical of buildings of this kind, known in Egypt in the early centuries of Roman dominance (Daszewski 1995: 1819, Figs 3, 4; Breccia 1923; Yegül 1992: 24, 29). It housed a set of main rooms typical of Hellenistic baths in Egypt (following the second model proposed by Monika Trümper, see Trümper 2009: 149, 152153). Situated in the center of the eastern area of the complex, the main bathing room was a tholos furnished with nine hip-bathtubs and one bigger bathtub, all of them placed side by side by its walls [see Fig. 2]. A small room (2) neighboring to the west housed an immersion tub. In two places in the baths there were stairs leading to the upper storey: in room $2 \mathrm{a}$ and in the western area of the complex. The main entrance to the complex led probably from the west, from a street running northwards from the main square of the town and beginning at the west end of its northern portico.

Relics of a heating device have survived in room 4, which is yet to be fully examined. The neighboring room (3) adjacent to the tholos on the north side is a water reservoir located on a high substructure. The construction of its walls is autonomous; they parallel walls of the neighboring rooms. It is probably only a construction phase. However, a similar situation is found in room 5 , which has its own walls built inside the perimeter of the main outer walls. In this case it may be the outcome of an alteration. A visible change (or a subsequent stage) was the walling up of the entrance in the east wall of this room at the southern corner, transforming it into a recess.

Red bricks discovered in room 5 may prove the existence of a heating system, which could be associated with the operation of the bath in Roman times. An additional entrance to the tholos from the south was a part of the refurbishment process, whereas partitioning the reservoir (3) with a wall and cutting an entrance in its south wall is evidence of alterations in late antiquity. Proof of other insignificant refurbishments can be found also in other parts of the complex.

Research conducted in the southern section of the bath complex enhanced identification of the functional layout of the baths, yet some issues of their functionality remain unexplained which, in turn, leaves identification of all the rooms subject to further research. The results confirmed, primarily, the existence of several phases of use over time, certified by rebuilding of 
the walls. At the same time, it should be remembered that the Hellenistic baths still functioned in a later period, simultaneously with the Roman baths built on the opposite side of the main square of the town (Southern Bath, see above, Czerner et al. 2016: 145ff., in this volume).

In the central and southern parts of the complex, the oldest phase comprised the central room of the tholos (1) together with a small room (2) and the staircase (2a), as well as another room (8) situated 2.45-2.75 $\mathrm{m}$ away from the tholos to the south, still without identified function [Fig. 9:a]. Room 8 and the tholos were linked by the east wall of room 6a and by a short eastern section of its south wall (with preserved relics of entrance jambs). Both walls were erected at the same time as room 8 and the tholos. Although the present west wall was built at a later time, rooms 6 and $6 a$ must have functioned as one room in the beginning. The floor in this room was made of mortar, repaired several times, and shaped so that it slopes towards the southwestern corner. A drain, $0.26 \mathrm{~m}$ wide and $1.20 \mathrm{~m}$, started from this corner, running north along the west wall [see Fig. 4]. The drain was used to discharge the water from the floor, which took on at the edge a more durable form of two stone slabs. Room 6 a was once roofed with a ceiling of palm beams covered with pugging, relics of which were found with impressions of the beams.

An entrance in the west wall of room 6 was constructed in the next phase of the functioning of the complex [Fig. 9:b]. However, it probably replicated the original layout. Two steps, leading down, had to be incorporated into this entrance because of the difference in floor levels, amounting to about $0.50 \mathrm{~m}$, between rooms 6 and 7 . This difference is due to the sloping of the floor in chamber 6 to the west (in the direction of the drain). The flooring of stone slabs in room 7 may date from this phase as well. Moreover, the rising ground south of the baths (porticoes of the main town square from the Roman period) necessitated

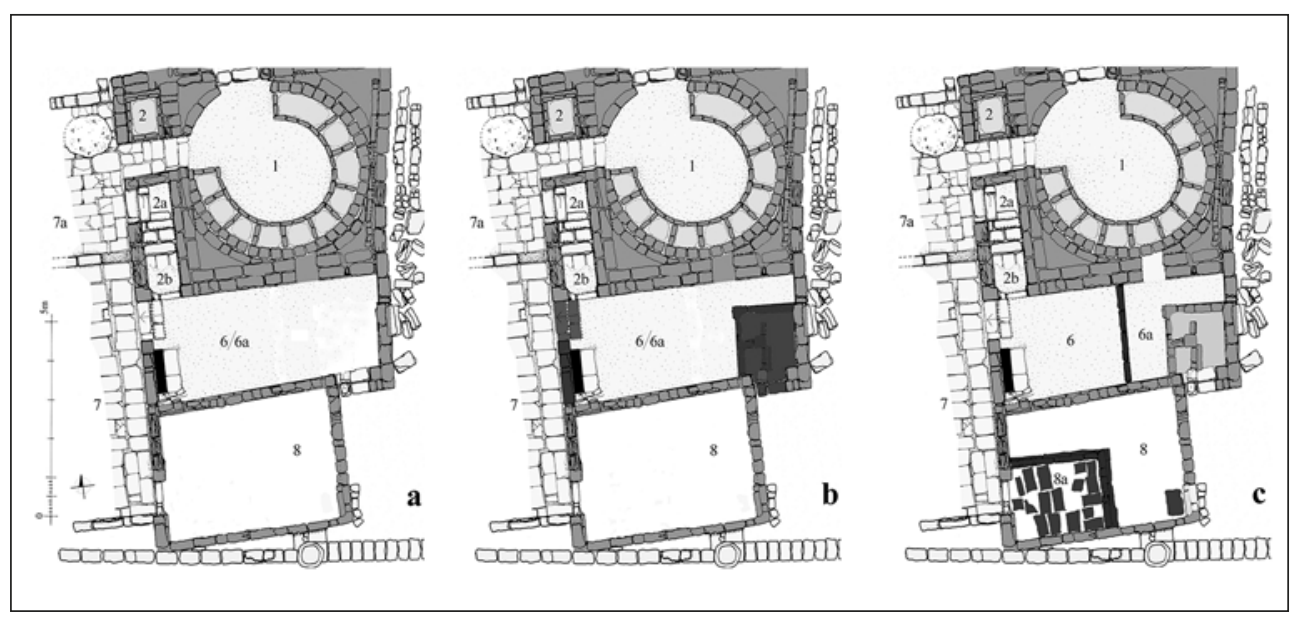

Fig. 9. Phases of development of the central and southern parts of the bath (Drawing R. Czerner) 
a new entrance to room 6a being made from this side on a correspondingly higher level. Next to it, a massive platform was built on the floor, perhaps as a a landing for another, wooden staircase leading to the upper storey [see Fig. 4]. The stairs in unit 2 should be noted as a parallel, being also built into the chamber walls.
Another alteration was the partitioning of room 6 a with a narrow wall and a new entrance to the tholos from the east. The most recent alteration was the contracting of room 8 to the size of room $8 \mathrm{a}$, and paving its floor with blocks from the former walls [Fig. 9:c].

\section{CONSERVATION WORK}

Conservation work was carried out in the tholos, neighboring room (2), staircase (2a), water reservoir (3), and in a set of rooms (6, 7, 8 and 8a) [Fig. 10]. The outer walls of the tholos are of limestone, and built on a quadrangular plan respecting the rules of block bonding. The order of stones in the walls remains the same across a section of all layers: every other layer is made of stones of smaller thickness (0.18$0.22 \mathrm{~m}$ ) alternating with thicker ones (0.31-0.27 m), the joint between them being $0.40 \mathrm{~m}$.

The gaps in the faces of the outer and inner walls were filled in [Fig. 11]. Stone came from an archaeological dump from 1987. Blocks were placed the patinated (hard) stone surface facing out. The work was done using lime-cement mortar (sand/lime/white cement 3:1.5:0.5). Gaps were carefully cleaned of stone powder, dust and detached remains of mortar, and the surfaces of stones in the wall, as well as of those used as fill were soaked in water, and then laid on a layer of mortar, making sure that all the joints between the stones were filled completely.

In room 2, some stones from the upper parts of the walls encasing the immersion bathtub were replaced.
Walls of the staircase (2a) and the stone steps were cleaned. The landing and the flight of stairs were closed with a wall from the north, reconstructing a corridor between the bathtub and the staircase [see Fig. 3]. Stone flooring in the corridor, made of limestone slabs, was also cleaned. Stone slabs in the partitioning wall separating the hallway from a storeroom (2b) accessible from the south survived in such poor condition that they had to be replaced. At the level of the upper landing the wall was partly reconstructed. The top layer of stones in the west wall, closing the staircase (2a), was levelled with mortar from the west and the joints were filled in.

In room 6 , in its east wall, the top layer was filled in, and in the northern corner a new higher layer was added in some places (stones $24 \times 28 \times 64 \mathrm{~cm}$ and $24 \mathrm{x}$ $28 \times 47 \mathrm{~cm}$ ), protecting in this way the eastern part of the room from drifted sand. In its west wall, two stone blocks ( 29 x 26 x $69 \mathrm{~cm}$ and $32 \times 28 \times 64 \mathrm{~cm}$ ), were replaced with different ones in better condition.

In rooms 8 and $8 \mathrm{a}$, some missing blocks in the surviving layers were replaced, while cracks in the remaining stone blocks were filled in with mortar, thus reintegrating the walls [Fig. 12]. 


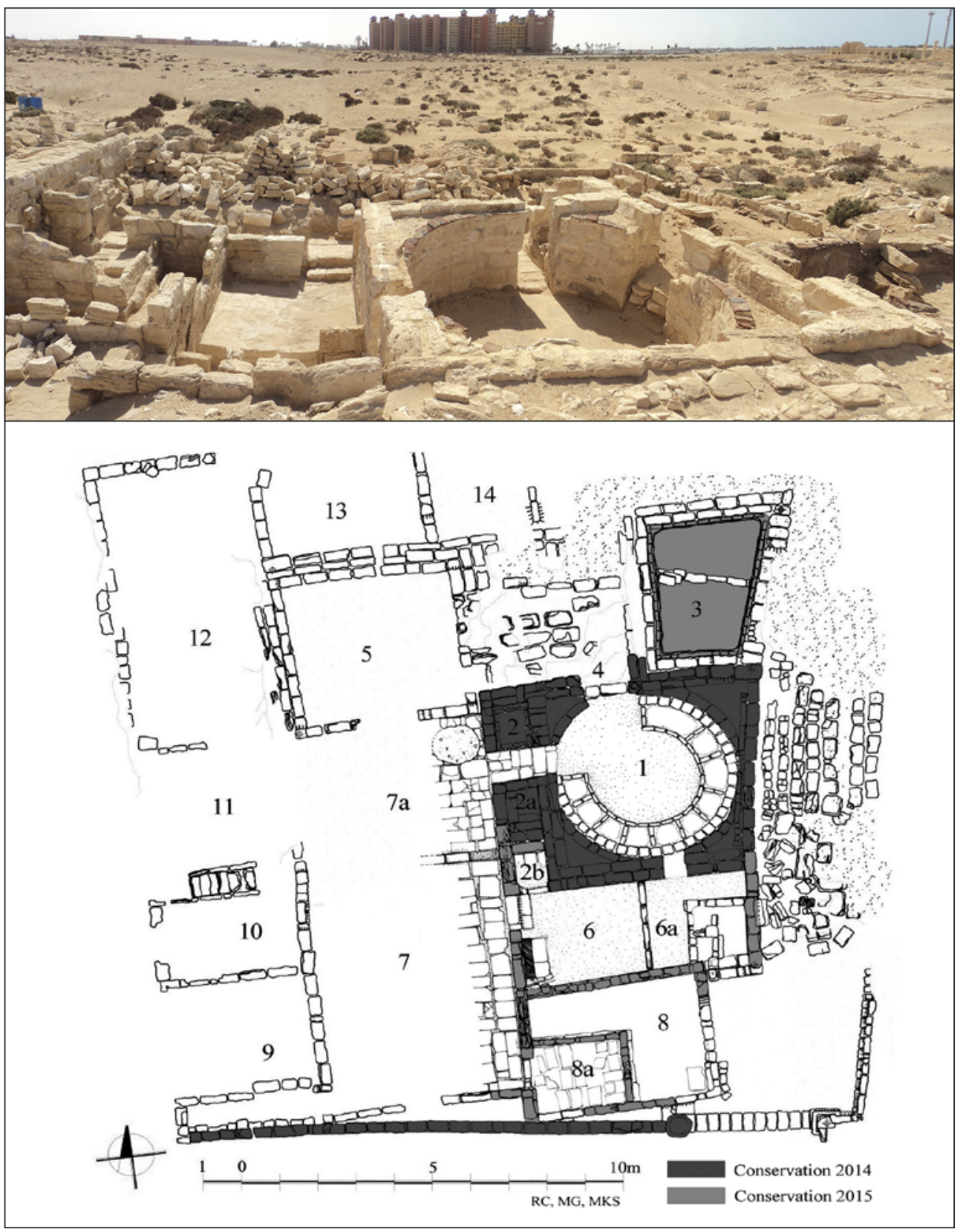

Fig. 10. Northern baths: areas subjected to conservation in 2014 and 2015; top, general view of the bath looking west (Drawing R. Czerner, M. Grzegorek, M. Krawczyk-Szczerbinska; photo W. Grzegorek) 
Research and conservation in Marina el-Alamein in 2014 and 2015...part two EGYPT

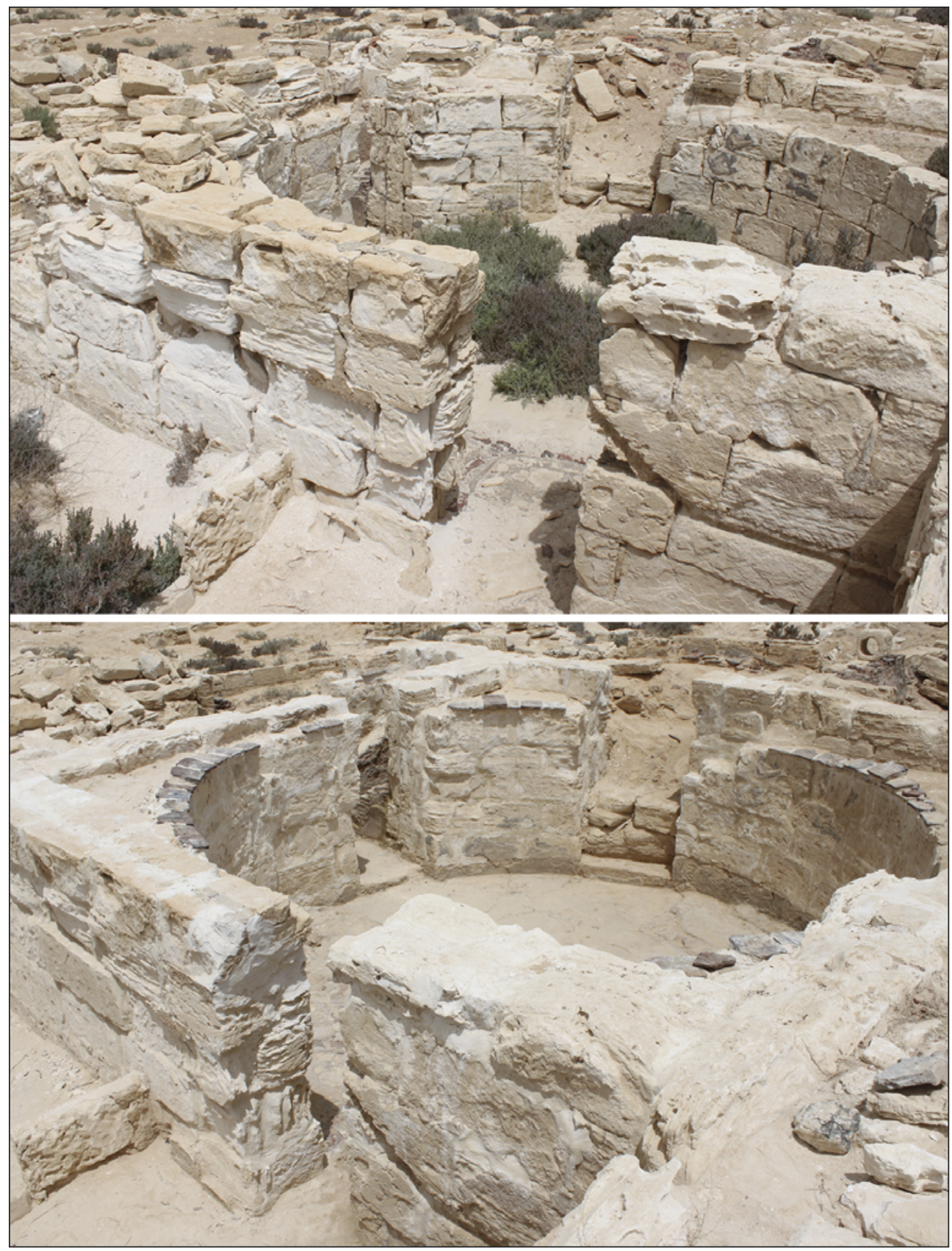

Fig. 11. The tholos before and after conservation in 2014, view from the east; note the restored outer face of the south wall [see also below, Fig. 2 on page 188] (Photos R. Czerner) 
A patch of plaster peeling from the south wall in room $7,74 \mathrm{~cm}$ high and about $80 \mathrm{~cm}$ wide, was conserved. The space between the plaster and the wall was cleaned of sand, and the fragment of plaster was reattached with mortar to the wall.

[WG]

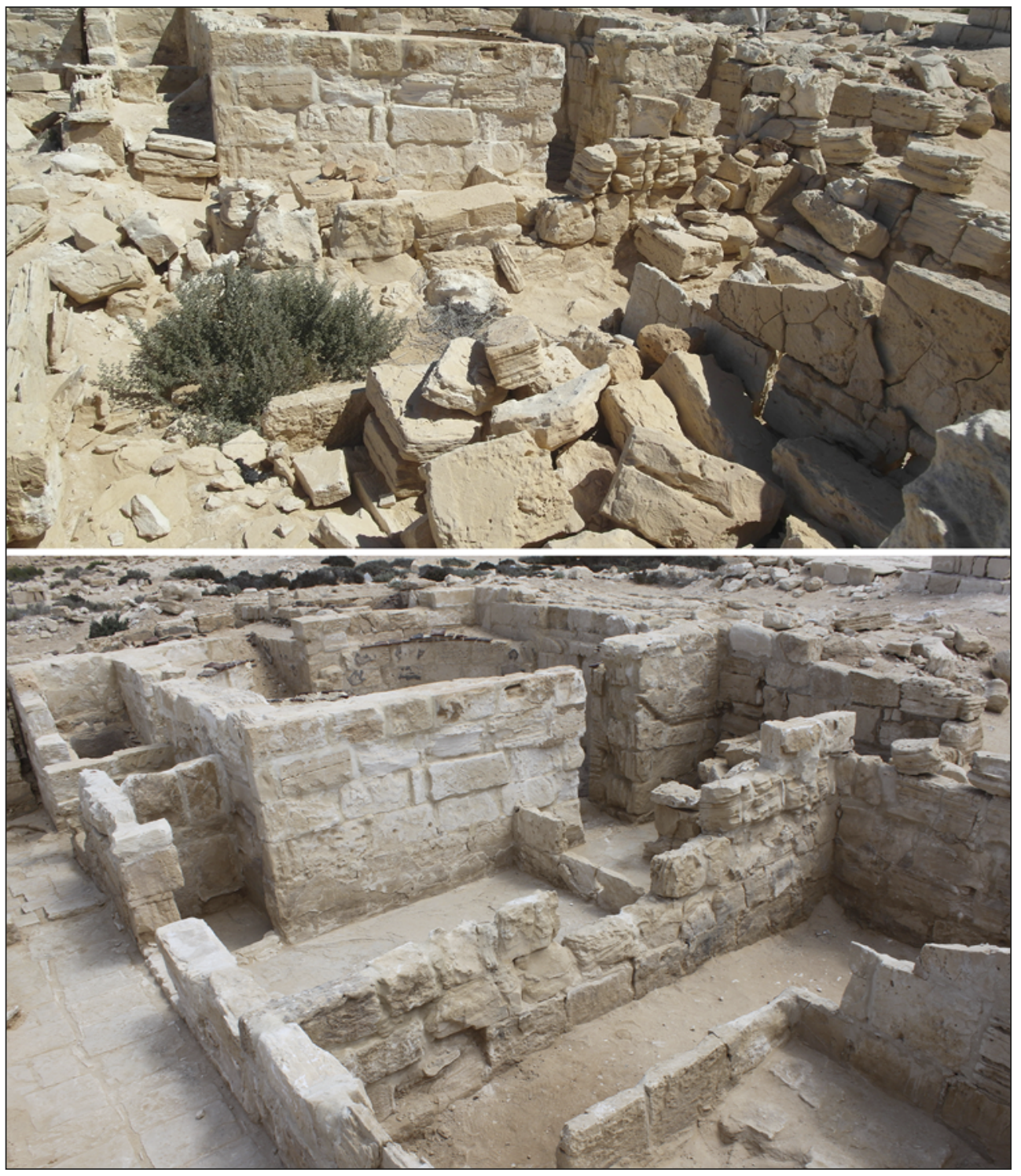

Fig. 12. The southern part of the bath, views before and after conservation (Photos R. Czerner) 


\section{Prof. Rafał Czerner}

Wrocław University of Science and Technology, Faculty of Architecture 50-317 Wrocław, Poland, ul. Bolesława Prusa 53/55

rafal.czerner@pwr.edu.pl

Dr. Grażyna Bąkowska-Czerner

Jagiellonian University, Center for Comparative Studies of Civilizations

31-044 Kraków, Poland, ul. Grodzka 52

grazyna.bakowska-czerner@uj.edu.pl

Wiesław Grzegorek

wieslawgrzegorek@wp.pl

Dr. Grzegorz Majcherek

Polish Centre of Mediterranean Archaeology, University of Warsaw

00-497 Warsaw, Poland, ul. Nowy Świat 4

g.majcherek@uw.edu.pl

\section{REFERENCES}

Becatti, G. (1941). Il Pothos di Scopa. Le Arti, 3, 401-412

Breccia, E. (1923). Di alcuni bagni nei dintorni d'Alessandria. BSAA, 19, 142-151

Czerner, R., Bąkowska-Czerner, G., Grzegorek, W., and Majcherek, G. (2016). Research and conservation in Marina el-Alamein in 2014 and 2015 (Polish-Egyptian Conservation Mission). Part one: The Southern Bath and central town square. PAM, 25, 145-166

Czerner, R., Bąkowska-Czerner, G., and Majcherek, G. (2015). Research and conservation in the Roman baths of Marina el-Alamein in the 2012 and 2013 seasons (Polish-Egyptian Conservation Mission). PAM, 24/1, 113-138

Daszewski, W.A. (1991). Marina El Alamein - the site of an unknown Graeco-Roman settlement on the Mediterranean coast of Egypt. In W.A. Daszewski, W. Bentkowski, U. Fidecka, A. Sawecki, J. Radzik, Z. Sztetyłł, and G. Majcherek, Marina El Alamein: Archaeological background and conservation problems. The Polish-Egyptian Preservation Mission at Marina, 1988. The Polish Excavation Mission at Marina, 1987-1989, I [=Reports of the Research-Conservation Mission of PKZ 18] (pp. 7-18). Warsaw: State Enterprise, the Ateliers for Conservation of Cultural Property (PKZ)

Daszewski, W.A. (1995). Témoignage de l'urbanisation de la côte méditerranéenne de l'Égypte à l'époque hellénistique et romaine à la lumière des fouilles de Marina el-Alamein. BSFE, $132,11-29$

Daszewski, W.A. (2011). Graeco-Roman town and necropolis in Marina el-Alamein. PAM, 20, 421-456

Dixneuf, D. (2011). Amphores égyptiennes: production, typologie, contenu et diffusion, III siècle avant J.-C-IX siècle après J.-C [=Études Alexandrines 22]. Alexandria: Centre d'études alexandrines

Fournet, T., Lucore, S.K., Redon, B., and Trümper, M. (2013). Catalog. In S.K. Lucore and M. Trümper (eds), Greek baths and bathing culture: New discoveries and approaches [=BABESCH Supplement 23] (pp. 269-333). Leuven-Paris-Walpole, MA: Peeters 
Hayes, J.W. (1985). Sigillate orientali. In Atlante delle forme ceramiche II. Ceramica fine romana nel bacino mediterraneo (tardo ellenismo e primo impero) (pp. 1-96). Rome: Istituto della Enciclopedia Italiana

Lund, J. (2000). The "pinched-handle" transport amphorae as evidence of the wine trade of Roman Cyprus. In G.K. Iōannidēs and S.A. Chatzēstyllēs (eds), Praktika tou Tritou Diethnous Kypriologikou Synedriou: Leukōsia, 16-20 Apriliou 1996 (pp. 565-578). Nicosia: Hetaireia Kypriakōn Spoudōn

Majcherek, G. (2007). Aegean and Asia Minor amphorae from Marina el-Alamein. In S. Marchand and A. Marangou (eds), Amphores d'Égypte de la Basse Époque à l'époque arabe I [=CCE 8/1] (pp. 9-31). Cairo: Institut français d'archéologie orientale

Majcherek, G. and Shennawi, A.A. (1992). Research on amphorae production on the northwestern coast of Egypt. CCE, 3, 123-136

Queyrel, F. (2014). Le garçon du Cricket et les enfants d'Alexandrie. In J.-Y. Empereur (ed.), Alexandrina 4. En l'honneur de Mervat Seif el-Din [=Études Alexandrines 32] (pp. 131161). Alexandria: Centre d'études alexandrines

Rieger, A.-K., and Möller, H. (2011). Kilns, commodities and consumers: Greco-Roman pottery production in Eastern Marmarica (Northwestern Egypt). AA, 2011(1), 141-170

Tomber, R.S. (1998). “Laodicean” wine containers in Roman Egypt. In O.E. Kaper (ed.), Life on the fringe: Living in the Southern Egyptian deserts during the Roman and early-Byzantine periods (pp. 213-220). Leiden: Research School CNWS, School of Asian, African, and Amerindian Studies

Trümper, M. (2009). Complex public bath buildings of the Hellenistic period. A case study in regional differences. In M.-F. Boussac, T. Fournet, and B. Redon (eds), Le bain collectif en Égyte: Balaneîa $=$ Thermae $=$ Hammâmât $[=$ Études urbaines 7] (pp. 139-179). Cairo: Institut français d'archéologie orientale

Yegül, F.K. (1992). Baths and bathing in classical antiquity. New York-Cambridge, MA: Architectural History Foundation; MIT Press 